\title{
Insulin-like growth factor-I and analogues increase growth in artificially-reared neonatal pigs
}

\author{
Frank R. Dunshea ${ }^{1}$, Chung S. Chung ${ }^{2}$, Phil C. Owens ${ }^{3} \dagger$, John F. Ballard ${ }^{3}$ and Paul E. Walton ${ }^{3} \ddagger$ \\ ${ }^{1}$ Victorian Institute of Animal Science, 600 Sneydes Rd., Werribee, Victoria 3030, Australia \\ ${ }^{2}$ Department of Animal Science, Chungbuk Natl U, Kaesin-Dong San 48, Cheongju, 360-763, Republic of Korea \\ ${ }^{3}$ Cooperative Research Centre for Tissue Growth and Repair, Adelaide 5000, Australia
}

(Received 27 March 2001 - Revised 16 January 2002 - Accepted 30 January 2002)

\begin{abstract}
Exogenous insulin-like growth factor (IGF)-I has been shown to increase growth rate in neonatal pigs while an analogue of IGF-I, long arginine (LR3) IGF-I, has been shown to be more potent than IGF-I in the rat. Therefore, two studies were conducted to determine whether IGF-I and LR3IGF-I increase growth in the artificially-reared neonatal pig. Expt 1 involved forty-two ( $2 \mathrm{~kg}$ initial weight) pigs infused with either control, IGF-I $(2,4$ or $8 \mu \mathrm{g} / \mathrm{h}$ ) or LR3IGF-I $(2,4$ or $8 \mu \mathrm{g} / \mathrm{h})$ infusions for $8 \mathrm{~d}$. Pigs were weighed and then offered $1.7 \mathrm{MJ}$ (gross energy) milk replacer $/ \mathrm{kg}^{0.75}$ per d. Expt 2 involved eighteen pigs ( $2 \mathrm{~kg}$ initial weight) treated with control saline, IGF-I $(8 \mu \mathrm{g} / \mathrm{h})$ or LR3IGF-I $(8 \mu \mathrm{g} / \mathrm{h})$ infusions. After $9 \mathrm{~d}$ an additional pump was inserted to increase the infusion rates of each of the growth factors $(16 \mu \mathrm{g} / \mathrm{h})$ for a further $9 \mathrm{~d}$. Cows' milk was provided ad libitum. In Expt 1 there was no overall effect of growth factors on daily weight gain or slaughter weight. However, milk intake was greater in pigs infused with growth factors $(909 v .867 \mathrm{~g} / \mathrm{d}, P=0.027)$, with an apparently greater milk intake by the pigs infused with IGF-I compared with LR3IGF-I $(920$ v. $898 \mathrm{~g} / \mathrm{d}$, $P=0 \cdot 12$ ). Infusion of LR3IGF-I decreased plasma IGF-I concentrations, but had no effect on plasma IGF-II concentrations. In Expt 2, neither IGF-I nor LR3IGF-I infusion had any effect upon daily weight gain over the first $9 \mathrm{~d}$ of the study. However, over the second $9 \mathrm{~d}$ of the study, daily weight gain was increased in LR3IGF-I-infused pigs (457 v. $386 \mathrm{~g} / \mathrm{d}, P<0 \cdot 01$ ), but not in pigs infused with IGF-I (413 v. $386 \mathrm{~g} / \mathrm{d}, P=0 \cdot 15)$. Milk intake was not different during the first $9 \mathrm{~d}$ of the study but was significantly greater in pigs infused with growth factors over the second half of the study (3407 v. $2905 \mathrm{~g} / \mathrm{d}, P<0 \cdot 01)$. Plasma IGF-binding protein-3 concentrations were highly correlated $(R=0.85)$ with average daily gain over the $3 \mathrm{~d}$ preceding blood sampling. In conclusion, exogenous IGF-I and particularly LR3IGF-I can increase growth rate and milk intake in artificially-reared pigs fed ad libitum but not in limit-fed piglets.
\end{abstract}

Insulin-like growth factor-I: Growth: Lactation: Somatotropin: Pig

The growth rate of the young pig is generally less than half its potential (Boyd et al. 1995) and may be constrained by endocrine status as well as nutrient intake. Although porcine somatotropin (ST) increases growth of grower and finisher pigs and is now commercially available in Australia for use in finisher pigs, the response to porcine ST is much less in neonatal pigs (Harrell et al. 1997; Dunshea et al. 1999). However, it has been shown that insulin-like growth factor (IGF)-I, the putative mediator of the effects of ST on lean tissue growth, can increase growth in normal and intra-uterine growth-retarded piglets
(Schoknecht et al. 1997). In addition, Schoknecht et al. (1997) found that IGF-I infusion stimulated protein deposition in the carcass, liver, spleen and jejunum of intra-uterine growth-retarded but not control piglets.

Researchers at the Cooperative Research Centre for Tissue Growth and Repair (Adelaide, Australia) have produced a recombinant analogue of IGF-I that is much more potent that IGF-I in stimulating growth in the rat (Tomas et al. 1992, 1993). Therefore, it may be possible that long-arginine (LR3) IGF-I stimulates growth of neonatal pigs to a greater extent than IGF-I. Consequently, the

\footnotetext{
Abbreviations: BP, binding protein; IGF, insulin-like growth factor; LR3, long arginine; ST, somatotropin.

* Corresponding author: Dr Frank R. Dunshea, fax +61 39742 0400, email Frank.Dunshea@nre.vic.gov.au

$\dagger$ Present address: Department of Obstetrics and Gynaecology, University of Adelaide, Adelaide 5000, Australia.

$\doteqdot$ Present address: JRH Biosciences, 13804 W. 107th Street, Lenexa, KS 66215, USA.
} 
following studies were conducted to determine whether IGF-I and LR3IGF-I could increase growth in artificiallyreared piglets.

\section{Materials and methods}

\section{Expt 1}

Forty-two cross-bred male piglets were weaned at between 24 and $48 \mathrm{~h}$ of age after each pig had obtained colostrum from their dam, been injected with $100 \mathrm{mg} \mathrm{Fe}$, and had their teeth clipped. After weaning, the pigs were transferred to individual wire mesh cages $(0.6 \times 0.45 \times 0.5 \mathrm{~m}$ high) located in an insulated building in which the ambient temperature was maintained at between 26 and $32^{\circ} \mathrm{C}$ with additional heat provided by a $175 \mathrm{~W}$ infra-red lamp. Between weaning and $2.0 \mathrm{~kg}$ live weight, piglets were trained to drink a high-protein liquid diet (Table 1) through rubber teats attached to a plastic hose inserted into a plastic container. The diet was formulated to ensure that the lysine and other amino acid of the diets were in excess of requirements by $20 \%$ (Auldist et al. 1997). Pigs were weighed daily until they reached $2.0 \mathrm{~kg}$ live weight when they were randomly allocated to either a control, IGF-I (2, 4 or $8 \mu \mathrm{g} / \mathrm{h})$ or LR3IGF-I $(2,4$ or $8 \mu \mathrm{g} / \mathrm{h})$ infusion for the duration of the experiment. IGF-I and LR3IGF-I were dissolved in $10 \mathrm{~mm}$-acetic acid and infusions were administered via a mini-osmotic pump (Alzet model 2001; Alzet, Palo Alto, CA, USA) inserted subcutaneously beneath the loose skin behind the ear. Control pigs received pumps containing vehicle. Pigs were weighed daily and the amount of feed offered adjusted to $1.7 \mathrm{MJ}$ digestible energy/ $/ \mathrm{kg}^{0.75}$ over two feeds at 09.00 and 16.00 hours. Spillage was collected in a container placed under the

Table 1. Composition of liquid diet used in Expt 1 ( $\mathrm{g} / \mathrm{kg}$ (air-dry basis) before being constituted with water)*

\begin{tabular}{lc} 
& g/kg (air-dry basis) \\
\hline Ingredient & \\
Butter oil & 191.8 \\
Lactose & $155 \cdot 7$ \\
Whey-protein concentrate & 323.9 \\
Skimmed-milk powder & 239.8 \\
Soyabean oil & 48.0 \\
Vitamin-mineral mix $†$ & 14.4 \\
Arginine & $6 \cdot 02$ \\
Valine & 5.90 \\
Histidine & 4.50 \\
Phenylalanine & 4.40 \\
Isoleucine & 3.24 \\
Tryptophan & 1.26 \\
Methionine & 1.08 \\
Composition & \\
Crude protein & 345 \\
Total lysine & 31 \\
Gross energy (MJ/kg) & 24 \\
\hline
\end{tabular}

* Diet was constituted with water to contain $200 \mathrm{~g}$ total solids/kg liquid.

$\dagger$ Provided the following nutrients $(\mathrm{mg} / \mathrm{kg}$ air-dry diet before constitution with water): retinol $3 \cdot 0$, cholecalciferol 0.03 , menadione $3 \cdot 3$, riboflavin $5 \cdot 0$, thia$\min 20, \alpha$-tocopherol 45 , nicotinic acid 35 , pantothenic acid 13 , pyridoxine 8, cyanocobalamin $0 \cdot 1$, biotin 0.2 , folic acid 0.5 , choline 3250 , Fe 60 , Mg $50, \mathrm{Mn} 45, \mathrm{Cu} 15, \mathrm{I} 0 \cdot 75$, Co $0 \cdot 2$, Se 0.3 . teat and under the cage. Refusals were also recorded. After $8 \mathrm{~d}$, pigs were bled via venepuncture for plasma IGF-I and IGF-II analyses before being killed with an intravenous injection of sodium pentabarbitone. Visceral tissues and organs were removed, the gastrointestinal tract emptied and all tissues and organs weighed.

\section{Expt 2}

Eighteen male crossbred pigs were trained to drink from teats and housed as described earlier for pigs in Expt 1 except that homogenized and pasteurized domestic cows' milk was used instead of a synthetic diet. Preliminary studies had demonstrated that pigs fed the same amount of energy as either cows' milk or the milk-replacer diet used in Expt 1 grew at the same rate (DE Auldist, personal communication). When pigs reached $2.0 \mathrm{~kg}$ live weight they were randomly allocated to either a control, IGF-I $(8 \mu \mathrm{g} / \mathrm{h})$ or LR3IGF-I $(8 \mu \mathrm{g} / \mathrm{h})$ infusion for the duration of the experiment. Infusions were given via a mini-osmotic pump (Alzet model 2001, Alzet) inserted behind the ear with control pigs receiving a pump containing vehicle. Cows' milk was provided ad libitum with the reservoirs being washed and refilled every $8 \mathrm{~h}$. After $9 \mathrm{~d}$, an additional pump was inserted to increase the infusion rates of each of the growth factors $(16 \mu \mathrm{g} / \mathrm{h})$. After $18 \mathrm{~d}$ pigs were killed and measures taken as in Expt 1. Pigs were bled via venepuncture for plasma IGF binding protein (BP)-3 analyses on days 0,9 and 18 .

\section{Chemical analyses}

Plasma was analysed for IGF-I, IGF-II and IGFBP-3 by radioimmunoassay. IGF-I and -II were dissociated and separated from IGF-BP by size-exclusion liquid chromatography of plasma at $\mathrm{pH} 2.5$ before assay (Owens et al. 1990). IGF-I and IGF-II radioimmunoassays were calibrated with porcine IGF-I and IGF-II (GroPep, Adelaide, Australia), respectively (Francis et al. 1989), and performed as previously described (Carr et al. 1995). IGFBP-3 was measured in diluted unextracted plasma by radioimmunoassay using an antiserum raised against IGFBP-3 purified from pig serum as previously described (Walton \& Etherton, 1989) except that the radioligand was prepared by chemically cross-linking ${ }^{125}$ I-labelled IGF-I (recombinant porcine; GroPep) to porcine IGFBP-3 (Baxter \& Martin, 1986). Intra- and inter-assay CV were 7.1 and $4.3 \%, 5.4$ and $11.4 \%$, and 7.9 and $21 \%$ for IGF-I, IGF-II and IGFBP-3 respectively.

\section{Statistics}

Data from Expt 1 were analysed to determine the overall effects of both growth factors, the individual growth factors, different doses and differences within growth factors. Data from Expt 2 were analysed to determine the effects of the overall response to both growth factors, the individual growth factors and differences within growth factors. All analyses were performed using GENSTAT (Payne et al. 1993; Lawes Agricultural Trust, Rothamsted, UK). 


\section{Results}

Expt 1

Growth data from Expt 1 are given in Table 2. While there was no overall effect of growth factors on daily weight gain or slaughter weight, pigs treated with IGF-I tended to grow faster than those treated with LR3 as indicated by the growth factor $\times$ IGF interaction for average daily weight gain $(201.3 v .194 .3 \mathrm{~g} / \mathrm{d}, P=0.085)$ and slaughter weight (3769 v. $3682 \mathrm{~g}, P=0.083$ ). Milk intake was greater in pigs infused with growth factors $(909 v .867 \mathrm{~g} / \mathrm{d}$, $P=0.027$ ), although this was primarily in the pigs infused with IGF-I rather than LR3IGF-I (920 v. $898 \mathrm{~g} / \mathrm{d}, P=0 \cdot 12)$. However, the milk consumed was used less efficiently in pigs infused with growth factors $(1.09 v .1 .13 \mathrm{~g}$ gain $/ \mathrm{g}$ DM consumed, $P=0.024)$. There were no effects of either growth factor on carcass weight or dressing out proportion. There was no effect of IGF-I on concentrations of IGF-I or IGF-II in plasma obtained on day 8 (Table 2), whereas LR3IGF-I infusion decreased plasma IGF-I concentrations but had no effect on plasma IGF-II concentrations (Table 2). There were relatively low levels of LR3IGF-I detected in only the pigs that received LR3IGF-I infusions (Table 2).

The effect of IGF-I and LR3IGF-I on organ weights is given in Table 3. In general there was little effect of growth factor upon organ weights. Pigs infused with the highest dose of LR3IGF-I had significantly larger kidneys than the other pigs as indicated by the growth factor $\times$ IGF $\times$ dose interaction $(P=0 \cdot 042)$.

\section{Expt 2}

Growth data from Expt 2 are given in Table 4. Neither IGF-I nor LR3IGF-I had any effect upon average daily weight gain over the first $9 \mathrm{~d}$ of the study. However, over the second $9 \mathrm{~d}$ of the study, average daily weight gain was increased in LR3IGF-I-infused pigs but not significantly in those pigs infused with IGF-I. As a result, pigs infused with LR3IGF-I were heavier than the control pigs at slaughter. Milk intake was not different during the first $9 \mathrm{~d}$ of the study, but was significantly greater in pigs infused with growth factors over the second half of the study. Feed conversion efficiency was not altered by infusion of growth factors nor was there any effect upon carcass weight or dressing-out proportion.

The effect of IGF-I and LR3IGF-I on organ weights is given in Table 5. In general there was a trend towards increased weight of organs with growth factor infusion but few of these differences reached significance, particularly when organ weights were expressed as a proportion of live weight (results not shown). However, pigs treated with LR3IGF-I did tend to have a larger liver (319v. $286 \mathrm{~g}, P=0.078)$, small intestine (383 v. $329 \mathrm{~g}, P=0 \cdot 10$ ) and combined small intestine and liver (701 v. $614 \mathrm{~g}$, $P=0.062$ ) weight. In addition, there was a significant increase in spleen size in pigs infused with LR3IGF-I $(27.5$ v. $18.9 \mathrm{~g}, P<0.001)$.

Plasma IGFBP3 concentrations increased with time on treatment, although there was a significant interaction between time and growth factor such that the pigs infused 
Table 3. Effect of dose of insulin-like growth factor (IGF)-I and LR3IGF-I on organ mass of limit-fed artificially-reared piglets (Expt 1)*

\begin{tabular}{|c|c|c|c|c|c|c|c|c|c|c|c|c|}
\hline \multirow{3}{*}{$\begin{array}{l}\text { IGF... } \\
\text { Dose }(\mu \mathrm{g} / \mathrm{h}) \text {. . }\end{array}$} & \multicolumn{7}{|c|}{ Growth factor } & \multirow[b]{3}{*}{ SED† } & \multirow{2}{*}{\multicolumn{4}{|c|}{ Statistical significance of effect $(P)$}} \\
\hline & \multicolumn{4}{|c|}{ IGF-I } & \multicolumn{3}{|c|}{ LR3IGF-I } & & & & & \\
\hline & 0 & 2 & 4 & 8 & 2 & 4 & 8 & & G & $G \times D$ & $\mathrm{G} \times \mathrm{I}$ & $G \times I \times D$ \\
\hline Liver (g) & 141 & 135 & 141 & 137 & 129 & 132 & 145 & $9 \cdot 3$ & 0.58 & 0.44 & 0.69 & 0.45 \\
\hline Heart (g) & $21 \cdot 8$ & $22 \cdot 3$ & 23.4 & 23.8 & 21.9 & $23 \cdot 8$ & $24 \cdot 3$ & 1.43 & 0.19 & 0.14 & 0.88 & 0.91 \\
\hline Kidney (g) & 33.9 & $33 \cdot 1$ & 34.9 & $32 \cdot 8$ & $32 \cdot 3$ & 34.7 & 38.8 & 2.03 & 0.75 & 0.098 & 0.16 & 0.042 \\
\hline Spleen (g) & 7.51 & 7.45 & 8.58 & 7.56 & 8.72 & 7.52 & 10.2 & 1.46 & 0.46 & 0.65 & 0.27 & 0.20 \\
\hline Stomach (g) & $17 \cdot 8$ & $19 \cdot 7$ & $18 \cdot 6$ & $20 \cdot 1$ & $18 \cdot 4$ & $19 \cdot 4$ & $17 \cdot \overline{3}$ & 1.29 & 0.24 & 0.89 & 0.15 & 0.16 \\
\hline Small intestine (g) & 165 & 165 & 172 & 173 & 163 & 174 & 174 & 9.49 & 0.47 & 0.30 & 0.92 & 0.95 \\
\hline Large intestine $(\mathrm{g})$ & 38.5 & 33.9 & $37 \cdot 7$ & $37 \cdot 7$ & 31.9 & $36 \cdot 4$ & $36 \cdot 1$ & 4.82 & 0.57 & 0.86 & 0.24 & 0.64 \\
\hline Caecum $(\mathrm{g})$ & 3.91 & 3.71 & 3.92 & 3.94 & 3.97 & 3.66 & $3 \cdot 71$ & 0.536 & 0.83 & 0.99 & 0.80 & 0.75 \\
\hline
\end{tabular}

I, IGF; LR3, long arginine; G, growth factor; D, dose.

${ }^{*}$ For details of diets and procedures, see Table 1 and p. 588.

† Standard error of the difference for minimum number of replicates (6 v. 6). For 36 v. 6,18 v. 18,18 v. 6,12 v. 12 and 12 v. 6 divide by $1.31,1.73,1.22,1.41$ and 1.15 respectively.

Table 4. Effect of dose of insulin-like growth factor (IGF)-I and LR3IGF-I on growth performance and carcass characteristics of artificiallyreared piglets fed ad libitum (Expt 2)*

\begin{tabular}{|c|c|c|c|c|c|c|}
\hline \multirow[b]{2}{*}{ IGF... } & \multicolumn{3}{|c|}{ Growth factor } & \multirow[b]{2}{*}{ SED $†$} & \multicolumn{2}{|c|}{$\begin{array}{c}\text { Statistical significance } \\
\text { of effect }(P)\end{array}$} \\
\hline & Control & IGF-I & LR3IGF-I & & G & $I \times G$ \\
\hline \multicolumn{7}{|c|}{ Daily weight gain $(\mathrm{g} / \mathrm{d})$} \\
\hline $0-9 d$ & 371 & 381 & 367 & $12 \cdot 4$ & 0.85 & 0.34 \\
\hline $9-18 d$ & 386 & 413 & 457 & $15 \cdot 2$ & 0.011 & 0.032 \\
\hline $0-18 d$ & 378 & 399 & 413 & $12 \cdot 6$ & 0.071 & 0.33 \\
\hline \multicolumn{7}{|l|}{ Milk intake (g/d) } \\
\hline $0-9 \mathrm{~d}$ & 2276 & 2314 & 2165 & $72 \cdot 4$ & 0.63 & 0.11 \\
\hline $9-18 d$ & 2905 & 3342 & 3472 & $152 \cdot 7$ & 0.009 & 0.48 \\
\hline $0-18 d$ & 2591 & 2828 & 2819 & $100 \cdot 6$ & 0.046 & 0.94 \\
\hline \multicolumn{7}{|l|}{ FCE (g/g DM) } \\
\hline $0-9 d$ & $1 \cdot 208$ & $1 \cdot 221$ & $1 \cdot 254$ & 0.0245 & 0.26 & 0.28 \\
\hline $9-18 d$ & 0.985 & 0.916 & 0.982 & 0.0445 & 0.44 & 0.23 \\
\hline $0-18 d$ & 1.083 & 1.041 & 1.085 & 0.0336 & 0.56 & 0.28 \\
\hline Final weight (g) & 8873 & 9227 & 9512 & $244 \cdot 5$ & 0.073 & 0.34 \\
\hline Carcass weight (g) & 6806 & 7113 & 7303 & 191.4 & 0.065 & 0.41 \\
\hline Dressing $(\mathrm{g} / \mathrm{g})$ & 0.766 & 0.771 & 0.768 & 0.0060 & 0.57 & 0.59 \\
\hline
\end{tabular}

G, growth factor; LR3, long arginine; I, IGF; FCE, feed conversion efficiency.

${ }^{\star}$ For details of diets and procedures, see Table 1 and p. 588.

† Standard error of the difference for minimum number of replicates (6 v. 6). For 12 v. 6 divide by 1.15.

Table 5. Effect of dose of insulin-like growth factor (IGF)-I and LR3IGF-I on visceral organ weights of artificially-reared piglets fed ad libitum $($ Expt 2)*

\begin{tabular}{|c|c|c|c|c|c|c|}
\hline \multirow[b]{2}{*}{ IGF... } & \multicolumn{3}{|c|}{ Growth factor } & \multirow[b]{2}{*}{ SED† } & \multicolumn{2}{|c|}{$\begin{array}{c}\text { Statistical significance of } \\
\text { effect }(P)\end{array}$} \\
\hline & Control & IGF-I & LR3IGF-I & & $\mathrm{G}$ & $\mathrm{I} \times \mathrm{G}$ \\
\hline Liver (g) & 286 & 303 & 321 & $17 \cdot 5$ & 0.11 & 0.35 \\
\hline Heart (g) & 53.4 & $53 \cdot 2$ & $57 \cdot 2$ & $4 \cdot 17$ & 0.63 & 0.37 \\
\hline Kidney (g) & $68 \cdot 8$ & $65 \cdot 8$ & $71 \cdot 8$ & $6 \cdot 21$ & 0.99 & 0.36 \\
\hline Spleen (g) & 18.9 & $16 \cdot 2$ & $27 \cdot 5$ & $2 \cdot 11$ & $0 \cdot 14$ & $<0.001$ \\
\hline Thymus (g) & $15 \cdot 4$ & $15 \cdot 1$ & $15 \cdot 5$ & 1.53 & 0.66 & 0.41 \\
\hline Stomach (g) & 41.4 & 39.4 & $39 \cdot 8$ & $3 \cdot 15$ & 0.53 & 0.91 \\
\hline Small intestine (g) & 329 & 349 & 380 & 33.3 & 0.25 & 0.37 \\
\hline Large intestine $(\mathrm{g})$ & $72 \cdot 1$ & 68.4 & $75 \cdot 0$ & 11.52 & 0.97 & 0.59 \\
\hline Caecum (g) & $19 \cdot 3$ & $18 \cdot 9$ & $18 \cdot 7$ & 2.72 & 0.85 & 0.96 \\
\hline
\end{tabular}

G, growth factor; LR3, long arginine; I, IGF.

* For details of diets and procedures, see Table 1 and p. 588.

† Standard error of the difference for minimum number of replicates (6 v. 6). For 12 v. 6 divide by 1.15. 


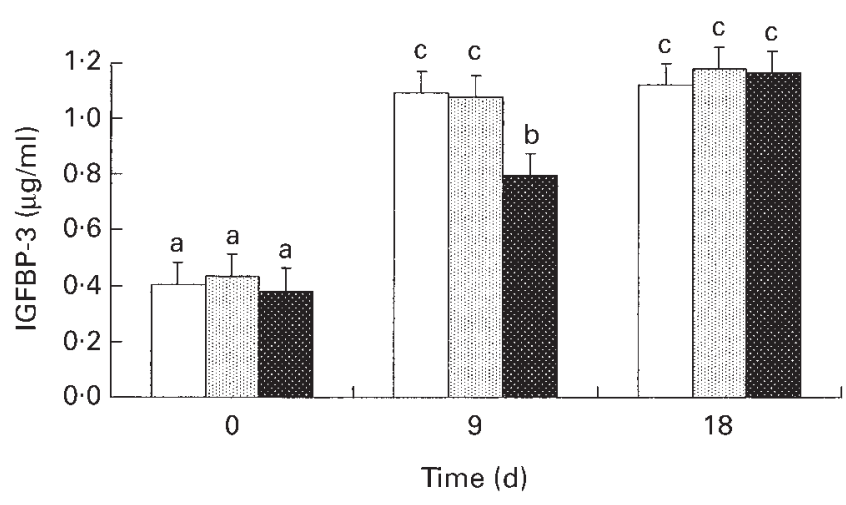

Fig. 1. Effect of time on treatment with insulin-like growth factor (IGF)-I or long arginine (LR3) IGF-I on plasma IGF binding protein (BP)-3 in neonatal pigs in Expt 2. $\square$, Control; $\square$, IGF-I; $\square$, LR3IGF-I. The infusion rates for the growth factors were $8 \mu \mathrm{g} / \mathrm{h}$ and $16 \mu \mathrm{g} / \mathrm{h}$ from days $0-9$ and $9-18$ of treatment respectively. For details of diets and procedures, see Table 1 and p. 588. Values are means for six pigs with standard errors of the difference shown by vertical bars. ${ }^{a, b, c}$ Mean values with unlike letters were significantly different $(P<0.05)$.

with LR3IGF-I had lower plasma IGFBP3 than the other treatments after $9 \mathrm{~d}$ of infusion, but that there was no difference after $18 \mathrm{~d}$ (Fig. 1). Plasma IGFBP3 concentrations were highly correlated $(R=0.85)$ with average daily weight gain over the $3 \mathrm{~d}$ preceding blood sampling (Fig. 2).

\section{Discussion}

IGF-I has been shown to acutely improve whole body and hindlimb $\mathrm{N}$ balance in protein-restricted pigs (Malmlof et al. 1994) and increase growth and $\mathrm{N}$ balance in rats (Tomas et al. 1992, 1993). However, when IGF-I has been administer for longer periods to finisher pigs fed protein-adequate diets they have had little effect upon growth (Walton et al. 1995). Indeed, under these conditions the potent analogues of IGF-I actually decrease performance

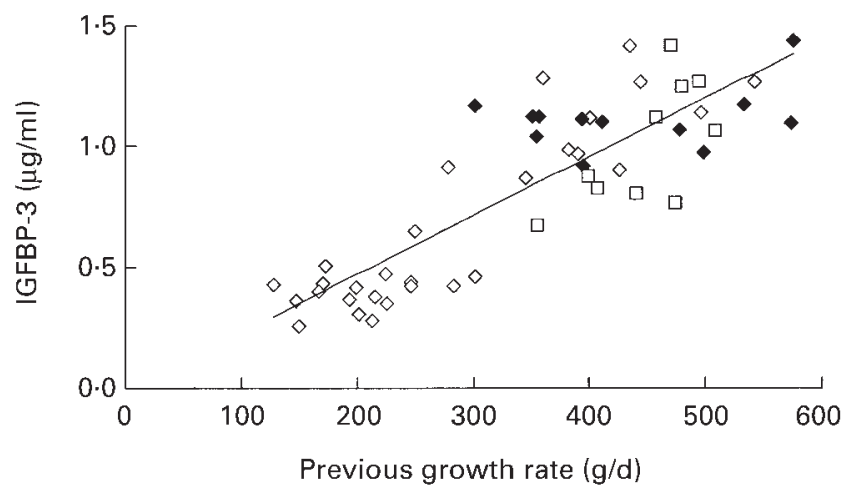

Fig. 2. Relationship between plasma insulin-like growth factor (IGF) binding protein (BP)-3 and growth rate over the $3 \mathrm{~d}$ prior to blood sampling in neonatal pigs infused with IGF-I or long arginine (LR3) IGF-I on plasma IGFBP-3 in Expt 2. $\diamond$, Control; $\bullet$, IGF-I; $\square$, LR3IGF-I. The infusion rates for the growth factors were $8 \mu \mathrm{g} / \mathrm{h}$ and $16 \mu \mathrm{g} / \mathrm{h}$ from days $0-9$ and $9-18$ of treatment respectively. Data are values for individual pigs bled on days 0,9 and 18 of treatment. For details of diets and procedures, see Table 1 and p. 588. Regression equation: $y=-0.0172+0.0024 \times(R=0.85, P<0.001$, $n 48)$. and circulating levels of endogenous IGF-I and the major binding proteins, possibly as a consequence of inhibition of endogenous porcine ST release (Walton et al. 1995; Dunaiski et al. 1997). Therefore, while it appears that IGF-I can increase or improve lean tissue growth in rats or protein-restricted finisher pigs, negative feedback mechanisms limit its usefulness in the finisher pigs fed adequate dietary protein. So what is different between rats and the finisher pig? The clue might lay in their relative sensitivity and responsiveness to exogenous ST.

The rat is relatively insensitive and unresponsive to exogenous ST but sensitive to the growth promoting properties of IGF-I and especially IGF-I analogues. On the other hand, the finisher pig is highly sensitive and responsive to porcine ST, relatively unresponsive to exogenous IGF-I and responds negatively to potent analogues of IGF-I. However, there is one class of pig that is unresponsive to porcine ST but whose potential for growth is relatively untapped, i.e. the neonate. The young pig is unresponsive to moderate doses of exogenous porcine ST up to at least 3-4 weeks of age (Harrell et al. 1994; Dunshea et al. 1999) at a time when endogenous production of porcine ST (Buonomo \& Klindt, 1993; Matteri \& Carroll, 1997) and the number of tissue porcine ST receptors are low (Holl et al. 1991; Duchamp et al. 1996; Schnoelbelen-Combes et al. 1996). Therefore, given the relative insensitivity to porcine ST of the neonatal pig it is possible that exogenous IGF-I or analogue treatment of baby pigs may not result in negative feedback inhibition of endogenous hormone secretion, and thereby allow the growth-promoting properties of IGF-I to be expressed. With this in mind, the present studies were conducted to determine the responses to IGF-I and LR3IGF-I in the neonatal pig.

In Expt 1, neither IGF-I or LR3IGF-I infusion had any effect upon growth in artificially-reared pigs that were restrictively-fed to grow at similar rates to those observed in pigs suckling the sow (about $200 \mathrm{~g} / \mathrm{d}$ ). On the other hand, Schoknecht et al. (1997) found that IGF-I infusion $(4 \mu \mathrm{g} / \mathrm{h})$ increased growth rate of suckling normal and intra-uterine growth-retarded piglets. The doses of IGF-I infused in the present study were $0 \cdot 5-, 1 \cdot 0$ - and 2.0-fold that used by Schoknecht et al. (1997), so it is somewhat surprising that a growth response was not observed. In the present study, plasma IGF-I was not increased at $8 \mathrm{~d}$ after commencement of the infusion and so it is possible, but unlikely, that the pumps had been exhausted. The specifications of the pump indicate that these pumps should deliver IGF-I for $8.7 \mathrm{~d}$ and in vitro tests as well as in vivo studies in older pigs have shown that the osmotic pumps deliver for approximately $9 \mathrm{~d}$, with a delay of approximately $4 \mathrm{~h}$ before they commence delivering material (FR Dunshea, unpublished results). In addition, it appears obvious that the LR3IGF-I was delivered since it was detectable in most samples from pigs infused with LR3IGF-I, despite LR3IGF-I being rapidly cleared from the circulation (Table 2). Using similar pumps, Schoknecht et al. (1997) found that plasma IGF-I concentrations were increased on days 1 and 4 in both normal and intra-uterine growth-retarded pigs but only in normal pigs on day 7 of infusion. Schoknecht et al. (1997) suggested that the 
infusion of IGF-I decreased endogenous IGF-I production and/or increased IGF-I clearance in the intra-uterine growth-retarded pigs, as was the case in protein-restricted rats (Thissen et al. 1992) and perhaps mediated via a decrease in IGFBP3. Certainly, infusion of LR3IGF-1 decreased plasma IGF-I concentrations in the restrictively-fed pigs in Expt 1, as happens in older, well-fed pigs (Dunaiski et al. 1997). Despite the lack of effect upon growth rate there did appear to be some biological effects of IGF in the restrictively-fed pigs in Expt 1. For example, pigs infused with IGF consumed more feed but used it less efficiently than the control pigs. Therefore, Expt 2 was conducted to see whether IGF-I or LR3IGF-I would increase feed intake and possibly growth in artificially-reared pigs allowed to consume milk ad libitum.

While neither IGF-I or LR3IGF-1 infusion $(8 \mu \mathrm{g} / \mathrm{h})$ had any effect upon feed intake or growth rate over the first $9 \mathrm{~d}$ of Expt 2, when the infusion rates were doubled $(16 \mu \mathrm{g} / \mathrm{h})$ there was an increase in feed intake and growth rate over the second $9 \mathrm{~d}$, particularly in pigs infused with LR3IGF-I. There was no effect of IGF on feed conversion. Although there were few significant effects of IGF on visceral organs, the liver and small intestinal weights tended to be greater in pigs infused with LR3IGF-I. While the delayed feed intake and growth response may be due to a lag in IGF action, it may be that the visceral responses precede the increase in peripheral tissue growth, particularly for LR3IGF-I. An increase in metabolic rate associated with greater visceral organ size would necessitate an increase in feed intake to provide sufficient energy and protein for growth. The restrictively-fed pigs that were infused with IGF in Expt 1 appeared to have higher maintenance requirements as indicated by the reduced feed efficiency but an unchanged growth rate.

Another possible reason for the difference in responses between Expts 1 and 2 is that different diets were used in each experiment. An artificial diet based predominantly on cows' milk-derived ingredients $(912 \mathrm{~g} / \mathrm{kg})$ was used in Expt 1 whereas whole cows' milk was used in Expt 2. The protein and lysine content of the diet used in Expt 1 was formulated to be sufficient to ensure that these macronutrients would be similar to those in cows' milk and not limit growth performance in either experiment (Auldist et al. 1997). While it is possible that the two diets contained different levels of IGF or other growth factors, given that the artificial diet used in Expt 1 was based on the milk-derived fractions that are enriched in growth factors (skimmedmilk powder and whey protein), it is unlikely that the differences in response between experiments were due to the type of diet used. Rather, it is more likely that the method of feeding (restricted feeding $v$. feeding ad libitum) contributed to the greater response in Expt 2.

The increase in feed intake in neonatal pigs receiving exogenous IGF has not been reported before. However, endogenous IGF-I concentrations have been found to be positively correlated with feed intake, P2 back fat and daily weight gain and negatively related to feed conversion efficiency in finisher pigs (Owens et al. 1999). Similarly, we have shown that plasma IGFBP3 and IGF-I are highly correlated with current growth rate (and presumably milk intake) in nursing piglets (Dunshea et al. 1999). The data from the pigs fed ad libitum in Expt 2 confirm the relationship between previous growth and plasma IGFBP3, regardless of whether they were infused with IGF-I or LR3IGF-I (Fig. 2). Owens et al. (1994) reported that IGF-I is a very good indicator of growth performance in the grower-finisher pig. More recently, Owens et al. (1997) showed that plasma IGF-I concentrations are more highly correlated with current than with future growth rate and suggested plasma IGF-I may be a reporter of, rather than a mediator of, growth performance in the pig. However, it appears that IGF-I and IGFBP3 production and/or clearance are not as sensitive to exogenous LR3IGF-I infusion in neonatal pigs, as compared with prepubertal (Dunaiski et al. 1997) pigs, thereby allowing growth and feed intake responses to be exhibited.

Another possible reason for the increase in feed intake and growth in the nursing and artificially-reared pigs consuming liquid diets, is that increased kidney function in IGF-infused pigs may stimulate milk intake and indirectly increase growth through increasing the supply of nutrients. In this context, IGF-I acutely increases glomerular filtration rate in human subjects before any change in kidney size could possibly occur (Giordano \& DeFronzo, 1995) while chronically increasing renal function in rats (Martin et al. 1991). However, kidney weight was relatively unaffected in the present studies, except at the highest dose of LR3IGF-1 in Expt 1.

\section{Conclusions}

Exogenous IGF-I and particularly LR3IGF-I can increase growth rate in artificially-reared neonatal pigs fed ad libitum but not in limit-fed neonates. At least part of the reason for this effect was an increase in milk consumption of infused piglets. Feedback inhibition of IGF-I and IGFBP3 production are not as great in the neonatal pig as they are in the finisher pig which may explain the differences in growth response. Plasma IGFBP3 was highly correlated with the previous growth rate of artificiallyreared pigs.

\section{Acknowledgements}

The authors wish to thank S. Shaw and D.J. Kerton for expert technical assistance in the conduct of the study and Pat Grant for conduct of IGF and BP assays.

\section{References}

Auldist DE, Stevenson FL, Kerr MG, Eason P \& King RH (1997) Lysine requirements of pigs from 2 to $7 \mathrm{~kg}$ liveweight. Animal Science 65, 501-507.

Baxter RC \& Martin JL (1986) Radioimmunoassay of growth hormone-dependent insulin-like growth factor binding protein in human plasma. Journal of Clinical Investigation 78, $1504-1512$.

Boyd DR, Kensinger RS, Harrell RJ \& Bauman DE (1995) Nutrient uptake and endocrine regulation of milk synthesis in mammary tissue of lactating sows. Journal of Animal Science 73, Suppl. 2, 36-56.

Buonomo FC \& Klindt J (1993) Ontogeny of growth hormone (GH), insulin-like growth factors (IGF-I and IGF-II) and IGF 
binding protein-2 (IGFBP-2) in genetically lean and obese swine. Domestic Animal Endocrinology 10, 257-265.

Carr JM, Owens JA, Grant PA, Owens PC \& Wallace JC (1995) Circulating insulin-like growth factors (IGFs), IGF-binding proteins (IGFBPs) and tissue mRNA levels of IGFBP-2 and IGFBP-4 in the ovine fetus. Journal of Endocrinology 145, 545-557.

Duchamp C, Butron KA, Herpin P \& Dauncey MJ (1996) Perinatal ontogeny of porcine growth hormone receptor gene expression is modulated by thyroid status. European Journal of Endocrinology 134, 524-531.

Dunaiski V, Dunshea FR \& Goddard C (1997) Regulation of insulin-like growth factor-I (IGF-I) and IGF binding protein-3 (IGFBP-3) mRNA by GH in different porcine tissues. Journal of Endocrinology 155, 559-565.

Dunshea FR, King RH, Owens PC \& Walton PE (1999) Moderate doses of porcine somatotropin do not increase plasma insulinlike growth factor-I or insulin-like growth-factor binding protein-3. Domestic Animal Endocrinology 16, 149-157.

Francis GL, Owens PC, McNeil KA, Wallace JC \& Ballard FJ (1989) Purification, amino-acid sequences and assay crossreactivities of porcine insulin-like growth factor I and II. Journal of Animal Science 72, Suppl. 1, 253.

Giordano M \& DeFronzo RA (1995) Acute effect of human recombinant insulin-like growth factor I on renal function in humans. Nephron 71, 10-15.

Harrell RJ, Thomas MJ, Boyd RD, Bauman DE, Czerwinski S \& Steele NC (1997) Ontogenic dependent response to exogenous porcine somatotropin in growing pigs. Journal of Animal Science 77, Suppl. 1, 253.

Holl RW, Snehotta R, Siegler B, Scherbaum W \& Heinze E (1991) Binding protein for hormone: effects of age and weight. Hormone Research 35, 190-197.

Malmloff K, Cortova Z, Saxerhalt H, Karlsson E \& Skottner A (1994) IGF-I and GH: Metabolic effects during experimentally induced catabolism. Growth Regulation 4, Suppl. 1, 51.

Martin AA, Tomas FM, Owens PC, Knowles SE, Ballard FJ \& Read LC (1991) IGF-I and its variant, des-(1-3)IGF-I, enhance growth in rats with reduced renal mass. American Journal of Physiology 261, F626-F633.

Matteri RL \& Carroll JA (1997) Somatotroph function in the neonatal pig. Domestic Animal Endocrinology 4, 241-249.

Payne RW, Lane PW \& Genstat 5 Committee (1993) Genstat 5 Reference Manual. Oxford: Oxford Science Publications.
Owens PC, Campbell RG, Francis GL \& Quinn KJ (1994) Growth hormone, gender and insulin-like growth factors: relationship to growth performance in pigs. Journal of Animal Science 72, Suppl. 1, 253.

Owens PC, Campbell RG \& Luxford BG (1997) Experimental correlations between insulin-like growth factors (IGF's) and growth rate show that endocrine IGF's are growth reporters, not drivers. In Manipulating Pig Production VI, p. 171 [PD Cranwell, editor]. Werribee, Victoria: APSA.

Owens PC, Gatford KL, Walton PE, Morley W \& Campbell RG (1999) The relationship between endogenous insulin-like growth factors and growth in pigs. Journal of Animal Science 77, 2098-2103.

Owens PC, Johnson RJ, Campbell RG \& Ballard FJ (1990) Growth hormone increases insulin-like growth factor-I (IGF-I) and decreases IGF-II in plasma of growing pigs. Journal of Endocrinology 124, 269-275.

Schnoelbelen-Combes S, Louveau I, Postel-Vinay MC \& Bonneau M (1996) Ontogeny of GH receptor and GH-binding protein in the pig. Journal of Endocrinology 148, 249-255.

Schoknecht PA, Ebner S, Skottner A, Burrin DG, Davis TA, Ellis K \& Pond WG (1997) Exogenous insulin-like growth factor-I increases weight gain in intrauterine growth-retarded neonatal pigs. Pediatric Research 42, 201-207.

Thissen JP, Davenport ML, Pucilowska JB, Miles MV \& Underwood LE (1992) Increased serum clearance and degradation of ${ }^{125}$ I-labeled IGF-I in protein-restricted rats. American Journal of Physiology 262, E406-E411.

Tomas FM, Knowles SE, Chandler CS, Francis GL, Owens PC \& Ballard FJ (1993) Anabolic effects of insulin-like growth factor-I (IGF-I) and an IGF-I variant in normal female rats. Endocrinology 137, 413-421.

Tomas FM, Knowles SE, Owens PC, Chandler CS, Francis GL, Read LC \& Ballard FJ (1992) Insulin-like growth factor-I (IGF-I) and especially IGF-I variants are anabolic in dexamethasone-treated rats. Biochemical Journal 282, 91-97.

Walton PE \& Etherton TD (1989) Effects of porcine growth hormone and insulin-like growth factor-I (IGF-I) on immunoreactive IGF-binding protein concentration in pigs. Journal of Endocrinology 120, 153-160.

Walton PE, Dunshea FR \& Ballard FJ (1995) In vivo actions of IGF analogues with poor affinities for IGFBPs: metabolic and growth effects in pigs of different ages and GH responsiveness. Progress in Growth Factor Research 6, 385-395. 